\title{
Cerca de la revolución colombiana. Repensando el unirismo de Jorge Eliécer Gaitán (1933-1935) ${ }^{1}$ Close to Colombian Revolution. Re-thinking the Unirismo of Jorge Eliécer Gaitán (1933-1935)
}

Doi:10.25100/hye.v17i56.11236

Artículo recibido: 22-04-2020. Artículo aceptado: 13-02-2021

\section{Cristian Acosta Olaya}

Universidad de San Martín- CONICET (Argentina)

Correo electrónico: cjacostao@gmail.com

ORCID: http://orcid.org/0000-0002-0415-1186

Forma de citar este artículo: Acosta Olaya, Cristian. "Cerca de la revolución Colombiana. Repensando en unirismo de Jorge Eliecer Gaitan (1933-1935)”. Historia y Espacio, vol. 17, nº 56 (2021): 361-398. Doi.org/10.25100/hye.v17i56.11236

1 Agradezco los comentarios y observaciones de Henry Alberto Cruz y de los evaluadores anónimos a una versión preliminar del presente artículo. Las deficiencias que este trabajo pueda tener son, por supuesto, de mi absoluta responsabilidad. 


\section{Resumen:}

Este trabajo estudia la construcción y disolución de la organización política Unión Nacional Izquierdista Revolucionaria (UNIR) de la primera mitad de la década de 1930 a través de la discursividad de su líder, Jorge Eliécer Gaitán, el testimonio de varios de sus miembros y el semanario 'Unirismo'. Desde el análisis de las identidades políticas, se indaga al unirismo en tensión con el comunismo y el liberalismo oficialista, para así destacar el sentido puntual de la acción revolucionaria unirista, marcado en gran parte por el pensamiento de Gaitán previo a 1933: el rechazo a la eliminación física de su alteridad y la vocación por construir una vanguardia política. Se propone, finalmente, que las fronteras identitarias establecidas contra el Partido Liberal desde la UNIR fueron porosas. Esta hipótesis cuestiona las lecturas acerca del unirismo como un intento de tercer partido y, fundamentalmente, explica el retorno de Gaitán al liberalismo sin recurrir a argumentos como la estrategia electoral o el oportunismo de dicho líder colombiano.

Palabras clave: unirismo, revolución, gaitanismo, identidades políticas, vanguardia

\section{Abstract:}

This paper studies the construction and dissolution of the political organization National Leftist Revolutionary Union (UNIR) form the first half of the 1930s through the discourse of its leader, Jorge Eliécer Gaitán, the testimony of several of its members and the weekly newspaper 'Unirismo'. Based on the political identities analysis, Unirismo is inquired here in tension with Communism and official Liberalism, in order to highlight the specificity of the revolutionary action of the UNIR, marked to a large extent by Gaitán's thought prior 1933: The rejection of the physical elimination of the otherness and the vocation to build a political Vanguard. Finally, it is proposed that the identity borders established by UNIR against the Liberal Party were porous. This hypothesis questions the readings about Unirismo as a third-party attempt and, fundamentally, explains Gaitán's return to liberalism without resorting to arguments such as electoral strategy or opportunism of the former Colombian leader.

Key Words: Unirismo, Revolution, Gaitanism, Political Identities, Vanguard 


\section{Cerca de la revolución colombiana. Repensando el unirismo de Jorge Eliécer Gaitán (1933-1935)}

\section{Introducción}

Resulta llamativo que en la mayoría de estudios sobre de la vida política de Jorge Eliécer Gaitán, la Unión Nacional Izquierdista Revolucionaria (UNIR) sea considerada como un impasse menor: su fugacidad como propuesta disidente del Partido Liberal, el fatal regreso de su principal líder al oficialismo y el argumento -harto verosímil- de que la inercia propia del bipartidismo lo absorbía todo en el contexto colombiano de los años treinta y cuarenta del siglo XX, son los principales motivos para devaluar la trascendencia de esta experiencia política. En el mejor de los casos, el unirismo ha llegado a ser descrito como una etapa efímera de Gaitán, la cual serviría para explicar, a manera de contraste, algunos rasgos posteriores del movimiento gaitanista de la década de 1940. De este modo, la UNIR vendría a ser el compendio de un entramado de ideas prematuras de Gaitán sobre el socialismo en Colombia; esta preocupación analítica, se supone, tendría su abrupto final cuando el líder unirista retornase, desde la segunda mitad de 1935, a la órbita del liberalismo con la "Revolución en Marcha" del presidente Alfonso López Pumarejo (1934-1938). ${ }^{2}$

Dicho retorno se traduce, según distintos autores, en que la radicalidad inicial de Gaitán en su juventud se fue eclipsando progresivamente con el despegue de su carrera política: en un continuum que va de la radicalidad a la moderación, el fracaso de la UNIR en 1935 se habría trasmutando en una paulatina conciliación de Gaitán frente el statu quo. Para Herbert Braun, por ejemplo, el fin del unirismo a mediados de 1935 da inicio a una progresiva adaptación de Gaitán dentro del establishment colombiano. Para este autor, Gaitán-entre 1936 y 1944-se habría vuelto “más moderado”, en comparación, se presume, a su época unirista, ocupando distintos cargos públicos y de

2 Sobre la relación entre la UNIR y el socialismo, ver el trabajo de José Gabriel Mosquera, "Unirismo: conformación de las luchas socialistas en Colombia" (Tesis de licenciatura en Ciencias Sociales, Universidad Nacional de Colombia, 1982). 
gobierno ${ }^{3}$ De manera similar, Joy Cordell Robinson asevera que en la etapa final del gaitanismo - que va desde 1946 hasta el asesinato de su líder en abril de 1948- "muchos elementos ideológicos sostenidos durante la primera etapa fueron abandonados a favor de una lucha constante, intensa y amarga por el poder, contra la organización liberal oficial y contra la administración conservadora". ${ }^{4}$

En contraste con lo anterior, en este trabajo se busca poner en cuestión los polos radicalidad/moderación para pensar el devenir político de Gaitán. Esto, sin embargo, no significa que se busque aquí una supuesta coherencia del gaitanismo en todas sus facetas, durante los años treinta y cuarenta del siglo XX. Antes bien, el presente artículo pretende indagar acerca de los presupuestos analíticos que asumen la diada revolución/evolución para pensar la primera etapa del gaitanismo. En este orden de ideas, y teniendo en cuenta que las indagaciones puntuales sobre las particularidades del proyecto unirista son prácticamente inexistentes, ${ }^{5}$ creemos pertinente auscultar la especificidad de la UNIR al interior de una constelación de proyectos políticos que se autodenominaron como "revolucionarios" para el decenio de 1930. Así, se contextualizará, en primer lugar, el debate latinoamericano sobre la revolución que tuvo lugar durante los años veinte y treinta del siglo XX y su variante directa en Colombia. Con esto, se quiere dar cuenta de la existencia de diversos sentidos que tenía el significante revolución para la época; sentidos en disputa y que fueron centrales para configurar distintas identidades políticas en el país.

En segundo lugar, se procederá a exponer la diferenciación entre socialismo y comunismo propuesta por Gaitán entre 1924 y 1933 y los enfrentamientos de este líder con el Partido Liberal, recién llegado al solio presidencial, sobre

3 Herbert Braun, Mataron a Gaitán. Vida pública y violencia urbana en Colombia (Bogotá: Norma, 1998), 141-142.

4 Joy Cordell Robinson, El movimiento gaitanista en Colombia: 1930-1948 (Bogotá: Tercer Mundo, 1976, 67.

5 El excelente trabajo de César Ayala Diago es, sin duda, la excepción que confirma la regla de una generalizada falta de interés por el devenir específico de la UNIR: César Ayala Diago, “La UNIR: entre Gaitán y los gaitanistas”, en La división creadora: influjo de las disidencias en el Liberalismo colombiano, ed. Rodrigo Llano Isaza (Bogotá: Academia Liberal de Historia, 2005), 135-152. También, y de manera reciente, el trabajo de Carlos Andrés Charry-Joya analiza el unirismo, enfocándose puntualmente en los atributos editoriales y materiales de dos de sus medios gráficos más representativos. Charry-Joya, Carlos Andrés, "Unirismo y Pluma Libre. Expresiones y transformaciones de la prensa gaitanista de los años 30", Sociedad yeconomía: 38 (2019): 64-88. 
la existencia de un "verdadero liberalismo". Finalmente, a través del análisis del semanario Unirismo (1934 y 1935) y de los testimonios de distintos uniristas, se pondrá a prueba la hipótesis central de este escrito: a diferencia de lecturas que consideran al unirismo como un proceso disidente o como un “tercer partido", la UNIR estableció un lazo identitario lábil y poroso frente a su principal adversario político, el liberalismo colombiano. Esta labilidad habilitaría el súbito retorno de Gaitán a las huestes de su partido a mediados de 1935 y la inmediata disolución del unirismo como organización política.

\section{Revolución y reformismo en América Latina a principios del siglo XX}

Según Vera Carnovale, en la América Latina de la década de 1920, diversos intelectuales de izquierda empezaron a discutir la idea de que la revolución, para ser alcanzada, precisaba primero atravesar una "etapa previa". Esta etapa correspondería, puntualmente, a una transformación nacional-democrática, basada en fundamentos antiimperialistas y antifeudales. Este etapismo suponía, en efecto, que para llegar al momento revolucionario era preciso primero atravesar un momento de transformación radical de los medios productivos por parte de las burguesías nacionales. ${ }^{6}$

Los desacuerdos respecto a lo anterior constituyeron tensiones, de índole política e intelectual, al interior de la izquierda latinoamericana, especialmente en la peruana. Esta discusión, que ciertamente trascendería al Perú, tomaría forma en las distintas desavenencias que existieron entre Raúl Haya de la Torre y José Carlos Mariátegui. Como lo resalta Carnovale, el pensamiento de este último fue uno de los antecedentes intelectuales más importantes de varias agrupaciones comunistas y guerrilleras de la región en los años sesenta y setenta del siglo XX, puesto que Mariátegui habría rechazado la idea de una "etapa previa” revolucionaria. El creador de Amauta, en efecto, cuestionó al rol "necesario" que el marxismo ortodoxo le había atribuido a la burguesía en el camino para poner fin al orden capitalista. La intervención de Mariátegui tenía lugar al interior de una disputa entre dos proyectos políticos divergentes: el socialismo ilustrado y el fascismo vitalista y místico. Frente a estas dos posturas, el marxismo de Mariátegui introdujo un tercer término: "el socialismo como romanticismo" ${ }^{7}$ En su famoso ensayo de 1925 , intitulado "Dos concepciones

6 Vera Carnovale, Los combatientes. Historia del PRT-ERP (Buenos Aires: Siglo XXI, 2011), $27-28$.

7 David Jiménez Panesso, "Revolución: imágenes, ideas, relatos”, en La República Liberal: sociedad y cultura, ed. Rubén Sierra Mejía (Bogotá: Universidad Nacional de Colombia-Facultad 
de la vida”, el pensador peruano aseguraba que después de la primera guerra mundial "[t]odas las energías románticas del hombre occidental [...] renacieron tempestuosas y prepotentes. Resucitó el culto de la violencia". ${ }^{8}$ Desde esta forma de entender las transformaciones políticas no había lugar alguno para los cambios progresivos, para una paciencia etapista a la que parecía apelar el reformismo. En realidad, al decir de David Jiménez Panesso, "Mariátegui estaba en guerra con el reformismo”, en tanto expresión máxima de un cálculo racional de la izquierda, por lo que aquel peruano se propuso "insuflarle un poco de espíritu romántico, de pasión por metas no calculables". ${ }^{9}$

Por su parte, la Alianza Popular Revolucionaria Americana (APRA) surge a mediados de la década de 1920 y su núcleo organizativo e intelectual giraría en torno al liderazgo del también peruano Raúl Haya de la Torre. Es sabido que la pretensión inicial del aprismo no fue constituirse como partido político exclusivo del Perú sino conformar una agrupación de carácter continental: el APRA buscaba, pues, colocarse a la cabeza de una creciente corriente de opinión "americanista y antiimperialista" ${ }^{10} \mathrm{Al}$ igual que otras agrupaciones que surgieron bajo el seno de las tradiciones del "socialismo ilustrado", entre el APRAy los sectores más insurreccionales de la izquierda peruana se estableció una tensión particular. Como lo expresaba a principios de 1935 un reconocido personaje del aprismo, Carlos Manuel Cox, la búsqueda de Mariátegui por erigir un Partido Obrero era infructuosa, pues en su país no había posibilidad para que existiera "la dictadura del proletariado"; esta "no puede ser efectiva en países de industrialismo incipiente y donde la clase obrera [...] no ha llegado a la madurez para abolir de un golpe la explotación del hombre por el hombre, imponer la justicia social, el socialismo en una palabra" ${ }^{11}$ En el marco de la discusión sobre la proximidad de Mariátegui a los preceptos marxistas, el intelectual peruano Juan Vargas respondía a la citada intervención de Cox - con evidente indignación-, considerando al APRA como un movimiento propio

de Ciencias Humanas, 2009), 419.

8 José Carlos Mariátegui, “Dos concepciones de vida”, en José Carlos Mariátegui: Obras, ed. Francisco Baeza (La Habana: Casa de las Américas, 1982), Tomo I, 409.

9 Jiménez Panesso, “Revolución: imágenes, ideas, relatos”, 420.

${ }^{10}$ Martín Bergel, "Populismo y cultura impresa: la clandestinidad literaria en los años de formación del Partido Aprista Peruano", Ipotesi 17 (2013): 136.

${ }^{11}$ Carlos Manuel Cox, “Aprismo y Marxismo en la obra de Mariátegui”, citado en: José Aricó, Mariátegui y los orígenes del marxismo latinoamericano (México DF: Siglo XXI, 1980), 21-22 - el resaltado es nuestro. 
de la pequeña burguesía peruana en defensa de los sectores más acaudalados del país. Al cooptar a amplios estratos del proletariado, aseguraba Vargas, el aprismo se vuelve tanto o más peligroso que la misma burguesía al poseer una investidura "revolucionaria". ${ }^{12}$

Ahora bien, la polémica al interior de la izquierda peruana tendría su propio eco en otros países de la región, la cual gravitaría sobre la forma de llevar a cabo -y la pertinencia o no de- un alzamiento insurreccional. De hecho, Medófilo Medina considera que la incipiente actividad obrera y artesanal en Colombia a principios del siglo XX propugnaba por la creación de un movimiento político nuevo - alejado del bipartidismo dominante--, que pudiese replicar en el país sucesos insurreccionales como la Revolución Rusa (1917) y la Revolución Mexicana (1910-1917). ${ }^{13}$ En consecuencia, se funda en 1919 el Partido Socialista (PS), cuyo programa en un principio no buscaba, según Medina, la abolición del Capital sino de los monopolios y privilegios de la elite económica. Pese a su fugaz duración -ya no existiría en 1923-, el PS marcaría un rasgo constante de la izquierda colombiana durante la primera mitad del siglo XX: su permanente preocupación por establecer relación con la Internacional Comunista. ${ }^{14}$ Consiguientemente, entre 1923 y 1926, se conformaron grupos autodenominados como socialistas en el marco de una agitada discusión entre sindicatos y organizaciones artesanales respecto a la creación de un Partido Obrero. En el Primer Congreso Obrero de Colombia, de mayo de 1924, se perfilaron dos tendencias en el socialismo colombiano de la época: una corriente "de tipo reformista", manteniendo la tradición del PS, y otra vertiente, para la cual "la revolución social era inminente"; esta última tendencia terminaría imponiéndose, por lo que se declaró eventualmente su adhesión a la Internacional Comunista, decretando el progresivo cumplimiento de los 21 puntos que Lenin había estipulado para concretar dicha adhesión. ${ }^{15}$ Dos años después, el Tercer Congreso Obrero declararía fundado el Partido Socialista Revolucionario (PSR). Al decir de Medina, "el nombre adoptado

12 Juan Vargas, “Aprismo y Marxismo” en: Aricó, Mariátegui y los orígenes, 33.

${ }^{13}$ Medófilo Medina, “Los terceros partidos en Colombia. 1900-1960”. En Nueva historia de Colombia, ed. Álvaro Tirado Mejía, Volumen II (Bogotá: Planeta, 1989), 263 y 265.

${ }^{14}$ Medina, "Los terceros partidos", 267-268.

${ }^{15}$ Klaus Meschkat, "La herencia perdida. Movimientos sociales y organización revolucionaria en la década de 1920: el caso del Partido Socialista Revolucionario en Colombia”, en El marxismo en Colombia, ed. Orlando Fals Borda (Bogotá: Universidad Nacional de Colombia-Facultad de Ciencias Humanas, 1983), 154. 
reflejaba la intención de recoger la tradición del partido y grupos socialistas que ya habían existido y, por otra parte, la necesidad de subrayar las diferencias ideológicas con el socialismo reformista". ${ }^{16}$

El socialismo reformista estaba encarnado, al decir de los socialistas, en la corriente izquierdista del Partido Liberal, pregonada principalmente por Rafael Uribe Uribe y Benjamín Herrera. A diferencia de estos líderes liberales, sin embargo, el PSR iniciaría la coordinación de actividades insurreccionales para derrocar al gobierno conservador de aquellos años. Según Klaus Meschkat, en tanto partido de masas que sus "contemporáneos juzgaron capaz de conquistar el poder”, el PSR fue adoptando la convicción de que un enfrentamiento armado contra los grupos dominantes del país era "inevitable", por lo que resultaba necesario llevar a cabo un alzamiento popular a nivel nacional. ${ }^{17}$ Para llevar a cabo esta insurrección generalizada, en julio de 1928 se crea el Comité Central Conspirativo y, en una pobre coordinación por parte de este organismo, un año después - a mediados de 1929-, se gestan diversas rebeliones por parte de núcleos socialistas en zonas rurales del país, siendo la más emblemática la de Líbano, en el departamento del Tolima. Estas sublevaciones, sin embargo, fueron rápidamente sofocadas por las fuerzas armadas conservadoras. ${ }^{18}$ Así pues, ya para 1930 la reorganización del PSR, debido a sus recurrentes fracasos, significó la progresiva integración de varios de sus miembros al liberalismo que recién llegaba al Poder Ejecutivo con Olaya Herrera y, a su vez, la adhesión de muchos socialistas radicales a las directrices de Moscú, lo que significó, en definitiva, la fundación del Partido Comunista (PCC). ${ }^{19}$

\section{El socialismo de Gaitán. Ni reforma ni precipitación}

En contraste con el embrionario comunismo de la época, varios líderes destacados del Partido Liberal tenían ya una concepción propia de la revolución. Esta diferenciación ha sido puesta usualmente en términos de contraposición

${ }^{16}$ Medina, "Los terceros partidos", 270. El PSR sería admitido a la Internacional Comunista en julio de 1928.

${ }^{17}$ Meschkat, "La herencia perdida”, 148 y 160. Al respecto, ver también: Isidro Vanegas Useche, "Apóstoles del pueblo. El carácter de los liderazgos revolucionarios en Colombia, 1924-1930", Historia y sociedad: 25 (2013): 53.

${ }^{18}$ Respecto a los hechos de dicho municipio, ver el capítulo “Los bolcheviques del Líbano” en Gonzalo Sánchez, Ensayos de historia social y política del siglo XX (Bogotá: El Áncora, 1985), 11-111.

${ }^{19}$ Medina, "Los terceros partidos en Colombia”, 274-275. 
entre revolución y evolución. Para Mauricio Archila Neira, por ejemplo, "al contrario de los marxistas”, Jorge Eliécer Gaitán “creía más en la evolución que en la revolución”; ${ }^{20}$ la evolución, en este sentido, guardaría un parentesco inobjetable con el reformismo, mientras que la revolución es entendida en su carácter unívocamente insurreccional; esta connotación sería la promulgada, entre otros, por actores políticos como el PCC en Colombia y, en Perú, por el mismo Mariátegui. Frente a lo anterior, una reflexión que evite replicar los calificativos a los que apelaban los actores mismos del periodo estudiado debería dar cuenta de que la distinción entre revolución y evolución, entre reforma y revolución, resulta ser menos autoevidente de lo que se cree. ${ }^{21}$ Que los sentidos de la revolución sean diversos implica que dichos sentidos han estado en permanente disputa por los actores políticos que la reivindican para sí. Para decirlo en otros términos: una conceptualización de la revolución que privilegie una perspectiva puntual -la insurreccional-termina soslayando las múltiples significaciones que adquirió la acción revolucionaria en las primeras décadas del siglo XX en Colombia.

Retomando el ejemplo de Archila Neira, en 1924 Gaitán presentó, en su tesis de grado para obtener el título de abogado en la Universidad Nacional de Colombia Lasideas socialistas en Colombia, un ideario revolucionario particular. ${ }^{22}$ A decir verdad, dicho escrito es sugestivo justamente porque retoma la idea de socialismo que circulaba en el país para estos años; al decir de Joy Cordell Robinson, la noción misma de socialismo usada en los años veinte colombianos buscaba "expresar cierto deseo de terminar con las injusticias económicas y sociales, y de reorientar el foco del interés político hacía los estratos más

${ }^{20}$ Mauricio Archila Neira, Cultura e identidad obrera. Colombia 1910-1945 (Bogotá: Cinep, 1991), 112-113.

${ }^{21}$ Reinhart Koselleck explica que la idea contemporánea de revolución, que surge a fines del siglo XVIII, devino en un concepto "perspectivista de carácter filosófico-histórico, que indicaba una dirección sin retorno"; ya desde el siglo XIX no debería parecer extraña la usual contaminación entre revolución y evolución: la posibilidad de intercambiar estos conceptos apunta a "desplazamientos estructurales en el conjunto del tejido social" que generan respuestas políticas diferentes: "[e]n un empleo antitético, evolución y revolución se convierten en conceptos partidistas". Reinhart Koselleck, Futuro pasado: para una semántica de los tiempos históricos (Barcelona: Paidós, 1993), 75-78.

22 Jorge Eliécer Gaitán, Las Ideas socialistas en Colombia (Bogotá: Centro Gaitán 1988). Es importante recordar que las ideas del joven abogado no surgieron ex nihilo; el ambiente intelectual de la década de 1920 era prolífico en discusiones políticas y culturales. Al respecto ver: Ricardo Arias Trujillo, Los leopardos. Una historia intelectual de los años 1920 (Bogotá: Ediciones Uniandes, 2007). 
bajos de la estructura social". ${ }^{23}$ En este sentido, la tesis de Gaitán parte de una hipótesis en boga para la época: allí se considerar al capitalismo como un sistema que funciona para producir riqueza, normalmente de tipo individual; siendo "el Capital" la riqueza empleada para la reproducción de esta última; la generación de grandes capitales individuales, por lo tanto, no significarían ningún beneficio para la "riqueza nacional" sino "la fuente de la injusticia social". ${ }^{24}$ El remedio del "problema social", al decir de Gaitán, no podía ser otro que "la socialización de los medios de producción”. ${ }^{25}$ De tal manera, en varios apartados de su escrito monográfico, el joven abogado considera al socialismo como la única forma de abolir la explotación entre los hombres; $\mathrm{y}$, haciendo un llamado a la redención de la "clase proletaria", al final de su tesis el autor insiste en la transformación radical de las leyes, tanto para evitar el reformismo -"el espejismo de sus transitorias bondades"- como para construir una "igualdad económica”, fundamento único de la libertad y del desarrollo pleno de los méritos. ${ }^{26}$

Ahora bien, con ciertas similitudes a las posturas del aprismo peruano, muchos apartados de Las ideas socialistas... sugieren que la revolución en Colombia tiene que realizarse a partir un análisis realista y prudente de las condiciones sociales, económicas y políticas del país. De hecho, Gaitán califica de "inocentada pueril" el hablar de comunismo en el país, más aun cuando no se ha iniciado siquiera "la primera labor seria en beneficio de los ideales socialistas", agregando posteriormente: "somos revolucionarios sí, y debemos serlo; pero lo que no somos es revolucionaristas. [...] El revolucionarista grita, trepida, desplaza atmósferas de iracundia inofensiva; y como su mirada no va al fondo, cree que basta para el triunfo total cambiar de nombres". ${ }^{27}$

El análisis del texto de Gaitán, de mediados de la década de 1920, permite inferir primeramente que una problematización de la distinción misma entre “revolución” y “evolución”. En su trabajo monográfico, el joven liberal planteaba no es solamente una concepción particular de lo que entiende por socialismo, sino que también expone el modo en el cual la revolución debería realizarse en Colombia: la instauración progresiva y autóctona del socialismo. De tal manera, el futuro jefe de la UNIR sugiere que aquella revolución evoluciona

\footnotetext{
${ }^{23}$ Robinson, El movimiento gaitanista, 30.

${ }^{24}$ Gaitán, Las ideas socialistas, 39-40.

25 Gaitán, Las ideas socialistas, 56-57.

${ }^{26}$ Gaitán, Las ideas socialistas, 149.

${ }^{27}$ Gaitán, Las ideas socialistas, 155 - las cursivas son del original.
} 
ineluctablemente hacia su concreción en la realidad del país, como si el debacle del Capital fuera inminente, deviniendo superfluas las acciones radicales e insurreccionales. ${ }^{28}$

Posteriormente, varios meses después de la represión a los trabajadores costeños acaecida en diciembre de 1928, el debate parlamentario propuesto por Gaitán sobre "la masacre de las bananeras" se pone en evidencia la disputa por los sentidos de la revolución que había en el país en esta la época. De aquel debate, en efecto, se podría destacar, en primer lugar, una concepción específica de la alteridad del pueblo colombiano esbozada por Gaitán: una parte minoritaria de la comunidad que, sin importar su pertenencia partidista, usa a las mayorías para usufructo propio. Sobre los partidos tradicionales, el 6 de septiembre de 1929, decía Gaitán que: "desgraciadamente no es el partido conservador el que hoy gobierna. Lo que hay es un gobierno de casta [...]; la entraña ciudadana palpita, no para rodear a la casta sino para destruirla, porque afortunadamente, yo percibo muy claro el galope de la revolución". ${ }^{29}$ Para Gaitán, ciertamente, aquella "casta" no es solo conservadora: en ella hay hombres políticos "de uno y otro partido", que traicionan a la masa "por los pequeños apetitos" ${ }^{30}$ En segundo lugar, la inevitable "reacción" del pueblo frente a la élite política empezaba a ser un tema recurrente en las intervenciones de Gaitán en estos años. En el Debate sobre las bananeras, de hecho, la construcción específica de una alteridad -"la casta", "los políticos inescrupulosos", etc.- es la cuestión que le habilita a este líder liberal aseverar que una acción revolucionaria es inminente. Esta perspectiva, sin embargo, no propone el advenimiento de un tiempo de reconciliación total; en cambio, Gaitán hace hincapié en que la revolución es una reacción natural u orgánica, casi catastrófica, que emerge de una injusticia imperecedera. Para él, la sublevación inevitable por la injusticia en Colombia se parecía a la figura del "taciturno ignorante", es decir, aquel que "sufre la ofensa, la acumula [...] hasta que un día, por cualquier motivo banal estalla de forma huracanada y terrible" ${ }^{31}$

En síntesis, si los postulados de Las ideas socialistas en Colombia proponen una revolución por la justicia social que debía construirse progresivamente, y si en sus intervenciones políticas antes de 1930, este líder liberal insiste constantemente sobre la idea de una hecatombe "purificadora" contra la

\footnotetext{
${ }^{28}$ Gaitán, Las ideas socialistas, 167.

${ }^{29}$ Gaitán, El Debate sobre las bananeras. Bogotá: Centro Gaitán, 1988, 51.

${ }^{30}$ Gaitán, El Debate sobre las bananeras, 56.

${ }^{31}$ Gaitán, El Debate sobre las bananeras, 22.
} 
injusticia: "los revolucionaristas" y el estallido de un taciturno social se contrasta, pues, con una idea particular de revolución. Alo anterior se le sumaba que la perspectiva de Gaitán sobre la revolución no se desarrollaría en tensión con un sistema dominado por el Partido Conservador sino respecto al Partido Liberal en Poder Ejecutivo desde 1930.

Desde aquel año, en efecto, las aspiraciones políticas de Gaitán se verían atravesadas por una turbulenta relación con el oficialismo liberal, en especial, con la posición crítica de este caudillo respecto al gobierno de Enrique Olaya Herrera (1930-1934). El cambio de mando presidencial influyó, por supuesto, a que Gaitán reformulara sus diatribas contra la "casta" política. Si bien algunas acciones del primer gobierno de la Hegemonía Liberal fueron, en sus inicios, aprobadas por Gaitán, ${ }^{32}$ ya para fines de 1932 la postura del joven dirigente era prácticamente de crítica respecto al accionar del presidente. Es más: Gaitán veía inaceptable que el Partido Liberal, ocupando ya el solio presidencial, siguiera defendiendo el orden económico y social heredado por el conservatismo. El liberalismo colombiano - según él- debería ser un partido revolucionario y proletario, aunque hacía la siguiente salvedad: "[la] revolución no significa demagogia y desorden, sino método, ponderación, equilibrio y avance" ${ }^{33}$ Para el periodo 1932-1933, Gaitán insistiría recurrentemente en una idea cardinal para sus proyectos políticos más inmediatos: la transición de un gobierno conservador a uno liberal no se tradujo en cambio alguno para las grandes mayorías del país. ${ }^{34}$

Puntualmente, en dicho periodo Gaitán destacaba que la revolución significaba tanto el debacle inminente de viejos órdenes como la reconstrucción de un orden institucional legítimo. El 18 de julio de 1932, por ejemplo, decía Gaitán en el congreso: "ya se verá [...] si en día no muy remoto se precipita una gigantesca campaña, una terrible revolución a favor de la ética, de lajusticia, de la

${ }^{32}$ En 1931 Gaitán consideraba que el gobierno de Olaya Herrera era capaz de reconocer "que sin la enérgica intervención del Estado la sociedad presente no puede manejarse ni marchar a la conquista de prósperos destinos”: Jorge Eliécer Gaitán, Los mejores discursos (Bogotá: Jorvi, 1968), 101.

${ }^{33}$ Gaitán, Los mejores discursos, 105-106.

${ }^{34}$ Como sostiene Gutiérrez Sanín, la propuesta de "Concentración Nacional” del gobierno de Olaya Herrera (1930-1934) tenía como pretensión principal replicar el pacto bipartidista implícito en la reforma constitucional conservadora de 1910, que hacía del partido opositor un "socio minoritario" del gobierno para evitar su radicalización: Francisco Gutiérrez Sanín, La destrucción de una República (Bogotá: Taurus-Universidad Externado, 2017), capítulos 6 y 7. 
sinceridad. [...]: cercano está el momento en que veremos si el pueblo manda, si el pueblo ordena, si el pueblo es pueblo y no una multitud anónima de siervos. ${ }^{35}$ De igual manera, y pese a las críticas al viejo orden, el joven parlamentario haría referencia a la relación entre el Partido Liberal y la revolución en términos complementarios: "no he proclamado el nacimiento de un nuevo partido. [...] El partido liberal tiene que ser, debe ser estrictamente revolucionario" ${ }^{36}$ En este orden de ideas, si el gobierno de Olaya Herrera había olvidado los orígenes revolucionarios de su partido, entonces el "verdadero liberalismo" no estaba conduciendo los destinos del país. ${ }^{37}$ Pero, ¿en qué consistiría, para Gaitán, este "verdadero" liberalismo, el liberalismo revolucionario?; ¿ ¿en qué medida estaba este en las antípodas del oficialismo liberal? A mediados de 1932, el próximo líder de la UNIR intentaba responder el último de estos interrogantes en los siguientes términos:

Voy a demostrar que los que me tachan son los que traicionan y han traicionado al partido liberal [...] Pero esta verdad no me autoriza a declarar una disidencia dentro de mi partido, ni la formación de uno nuevo. Es que yo no soy el disidente sino que los disidentes son ellos. [...] Yo soy, ante todo, anticonservador porque soy revolucionario. ${ }^{38}$

De esta manera, la pertenencia al liberalismo, antes de ser una cuestión brindada por la afinidad al oficialismo, implicaba para Gaitán una coherencia con la tradición del partido, con una heredad que, en gran medida, evocaba las pugnas civiles decimonónicas. El rescate de esta tradición, a su vez, le permite a dicho líder proponer lo que vendría a ser lo genuinamente liberal y constituir una alteridad conservadora: esta última no dejaría de pertenecer al orden conservador aunque tuviese la rúbrica liberal.

En resumen, entre los albores de la década de 1930 hasta el momento previo a la fundación de la UNIR, los sentidos de la revolución aparecen en las intervenciones de Gaitán reenviándose a un cambio radical que el país necesita y cuya postergación implicaría el despliegue irrefrenable de fuerzas desorganizadas. El contraste entre revolucionarios y "revolucionaristas" le permitía al futuro jefe del gaitanismo distanciarse de los comunistas de su época

\footnotetext{
35 Gaitán, Los mejores discursos, 110.

${ }^{36}$ Gaitán, Los mejores discursos, 110.

37 Gaitán, Los mejores discursos, 111.

${ }^{38}$ Gaitán, Los mejores discursos, 111-112 - el resaltado es nuestro.
} 
y, a su vez, lo habilitaba a enarbolar-según él-las ideas trasformadoras de un verdadero liberalismo, de cuño revolucionario, que todavía no había llegado al poder en Colombia. Esta particular concepción de la acción revolucionaria, antes que menguar, se hace aún más presente en el periodo unirista de Gaitán.

\section{De "los disidentes son ellos” a la Unión Nacional Izquierdista Revolu- cionaria, UNIR (1933-1935)}

La UNIR -más allá de su corta duración-fue un interesante intento de construir una fuerza aglutinadora de liberales que tomaron crítica distancia del bipartidismo tradicional. ${ }^{39}$ Para hablar en profundidad del unirismo es obligatorio recurrir al libro testimonial de uno de sus integrantes más emblemáticos e importantes: Fermín López Giraldo. ${ }^{40}$ Efectivamente, en su obra de 1936, López Giraldo narra una historia bastante particular de la UNIR y que tiene como epicentro argumentativo una caracterización de Gaitán en tanto "traidor de las masas", debido a su regreso a las filas del Partido Liberal a mediados de 1935. Si bien, como se expuso anteriormente, en varias intervenciones de aquel líder liberal la creación de un tercer partido parecía ser una necedad hasta antiliberal, para el autor de El apóstol desnudo, en cambio, el surgimiento de la UNIR tenía como leitmotiv combatir a un Partido Liberal que, desde 1930, se había "conservatizado al poder" y que tenía para las masas populares solo "la evasiva cobarde o la bala homicida". ${ }^{41}$

Con estos presupuestos, la Unión Nacional Izquierdista Revolucionaria nace el 20 de abril de 1933, según López Giraldo, como un acuerdo de los jóvenes líderes Jorge Eliécer Gaitán y Carlos Arango Vélez. Ambos formarían un "partido o conglomerado político" que representara las facciones del socialismo provenientes del Partido Liberal y que fueron obliteradas por el oficialismo. La primera acción importante del grupo unirista fue construir símbolos de identidad que lo distanciara del partido de gobierno ${ }^{42}$ creando un escudo y

39 Se evita hablar aquí de disidencia por ser generalmente un término nativo, alejado de toda especificidad analítica y que suele emplearse de manera acrítica para pensar experiencias políticas similares a las "fracciones" o "facciones" partidistas. Una reflexión teórica sobre la disidencia, creemos, es una tarea pendiente de las ciencias sociales contemporáneas en América Latina.

${ }^{40}$ Fermín López Giraldo, El apóstol desnudo, o dos años al lado de un mito (Manizales: Editorial Zapata, 1936).

${ }^{41}$ López Giraldo, El apóstol desnudo, 14.

${ }^{42}$ Ayala Diago, “La UNIR: entre Gaitán y los gaitanistas”, 102. 
una bandera con los colores rojo y negro, acompañados del lema "MUERTE AL PASADO, REVOLUCIÓN HACIA EL PORVENIR". ${ }^{43}$ Es importante destacar que, a diferencia de otras agrupaciones que surgieron a lo largo de la República Liberal (1930-1946) y que se presentaban como opciones alternativas $₫$ tanto

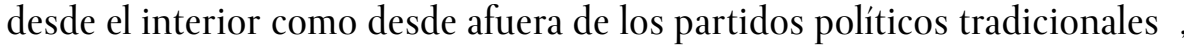
en la misma base programática de la UNIR estaba presente cierta ambivalencia para definirse como un partido político propiamente dicho. Términos como "conglomerado", "fuerza", entre otros, serían usados por los uniristas para definir su agrupación. Si bien López Giraldo afirmaba que su llegada al unirismo, como la de "los demás afiliados", se debía a un convencimiento de la necesidad de participar en los asuntos políticos colombianos y trabajar "independientemente de los partidos tradicionales por el implantamiento [sic] en Colombia de las ideas socialistas [...]", ${ }^{44}$ lo cierto es que la primer Acta de la UNIR no daba luz verde para la consolidación de un partido político. Esto se debía, según la organización, al escozor que generaba el término "partido" al interior del unirismo:

PRIMERO: La ideología por la cual luchará la UNIR será la socialista. [...] SEGUNDO: La UNIR aspira a ser un poder fiscalizador dentro de la vida nacional [...] TERCERO: La UNIR, que no quiere proclamarse como un partido político en el sentido de interpretación usual en el país, pretende ser una Organización libre, responsable y consciente, tendiente únicamente a la realización de sus fines. ${ }^{45}$

Ciertamente, esta ambigüedad entre la formación de un "tercer partido" y no querer ser otra organización partidista más -"en el sentido de interpretación usual”-, estaría presente durante los más de dos años de existencia del unirismo. Recién conformada la UNIR, no tardaron en arreciar críticas de distintos los frentes políticos tildando a la agrupación de ser tanto una estrategia del comunismo como una manifestación del fascismo en Colombia. Frente a esto, en la defensa esgrimida por Gaitán en el Congreso - de agosto de 1933- se argumentaba, primero, que la UNIR no era fascista porque no pregonaba "la dictadura del Estado por el Estado mismo" y, segundo, que tampoco era comunista, ya que rechazaba "la dictadura de la clase proletaria

${ }^{43}$ López Giraldo, El apóstol desnudo, 45 - en mayúsculas en el original.

${ }^{44}$ López Giraldo ingresaría en junio de 1933 al unirismo, alcanzando el cargo de "Inspector General”: López Giraldo, El apóstol desnudo, 49.

45 “Primer Acta de la UNIR”, citada en López Giraldo, El apóstol desnudo, 47. 
sobre las otras clases", dictadura "en todas sus formas absolutamente ajena a nuestro pensamiento y sentido políticos”. Y, sobre al tema de la conformación de un tercer partido, agregaba Gaitán que "el unirismo no solo no rechaza sino que acepta el principio democrático, y de fijar nuestro rumbo de simple organización y no de partido pues todavía no somos partido" . ${ }^{66}$ La UNIR parecía ser, entonces, una "fuerza" sin pretensiones electorales. ${ }^{47}$

Es importante resaltar, sin embargo, que esta constante reticencia de Gaitán para referirse al unirismo como un partido parecía ser rebatida por algunos de sus propios militantes. Este es el caso no sólo del testimonio a posteriori de López Giraldo; lo anterior se evidencia también en las misivas uniristas enviadas a Gaitán durante aquellos años. Por ejemplo, en una carta proveniente de Socorro (departamento de Santander) y fechada en mayo de 1934, se le dice al jefe de la UNIR que las divisiones entre los partidos tradicionales no son ideológicas ni programáticas sino que tienen meros fundamentos "presupuestales" y que, por tales motivos, empezaba a emerger "una tendencia a la fundación del partido de clase y la esperanza del proletariado en el partido que Ud. organiza”. ${ }^{48}$ Ahora bien, si esta supuesta contradicción pueda ser entendida como una cuestión mínima de diferencias en la nominación-percibirse como "partido" u "organización" daría lo mismo-aquí se considera, en contraste, que la fragilidad del proyecto unirista se debió precisamente a esta tensión entre, por una parte, desmarcarse precariamente de la estructura de partidos imperante en Colombia y, por otra parte, buscar constituirse como una alternativa radical al bipartidismo. Dicho en otros términos: al tiempo que los uniristas espetaban un confuso rechazo frente al apelativo partidista, se atribuían un rol de fuerza política que luchaba por deponer un orden conservador; orden este, que no había sido desmantelado por el Partido Liberal desde el Poder Ejecutivo. ${ }^{49}$

${ }^{46}$ Gaitán, Los mejores discursos, 118 - el resaltado es nuestro.

${ }^{47}$ Gaitán, Los mejores discursos, 133. En su época de formación, entre abril de 1933 y junio de 1934, los únicos escritos oficiales de la UNIR eran la "Primer acta", antes citada, y un documento titulado "Boceto del programa unirista", en cuyos primeros dos puntos se afirmaba: " $1^{\underline{o}}$ No somos un partido. Somos una Organización. $2^{\underline{0}}$ De momento no tenemos ambiciones electorales. Primero es organizarse y disciplinarse. Después la lucha”: López Giraldo, El apóstol desnudo, 53.

48 Carta de Juan de Dios Riberos a Jorge Eliécer Gaitán, Socorro (Santander), 12 de mayo de 1934. Fondo Académico Jorge Eliécer Gaitán Ayala, Archivo Central e Histórico-Universidad Nacional de Colombia, sección "Adhesiones uniristas".

${ }^{49}$ Se podrá objetar que revisar esta tensión al interior de la solidaridad unirista - esto es, entre ser una organización política alternativa al bipartidismo y desdeñar de ser un partido conso- 
Como ya se dijo anteriormente, la búsqueda de la UNIR por constituirse en una organización que ponía en cuestión el orden político iniciado por el liberalismo en 1930 no resulta ser una cuestión menor. Por ejemplo, en una editorial del periódico adepto al unirismo Pluma Libre, de Pereira, se buscaba poner de relieve la inexistencia de un quiebre frente al sistema pasado, propio del conservatismo, con la llegada del Partido Liberal al poder. Por lo tanto, se hacía allí un llamado - en marzo de 1934-a la desvinculación total de la UNIR frente al liberalismo:

Ayer pecábamos como enemigos de los conservadores, hoy pecamos como copartidarios de los liberales; ayer denunciábamos un atropello, hoy denunciamos un crimen; ayer supimos de unos desfalcos, hoy nos damos cuenta de unas quiebras en las administraciones de hacienda; ayer se asesinaba en la plaza pública unos obreros, hoy se asesinaba en el campo centenares de labriegos; ayer se impedía el derecho de reunión, hoy se impide el derecho de palabra. ${ }^{50}$

Por otra parte, el lazo con el pasado conservador que representaba el gobierno de Olaya Herrera y el Partido Liberal no es el único antagonismo constitutivo de la identidad unirista. Además del rechazo explícito al Partido Conservador, en un contexto de multiplicación de actores de izquierda en el escenario político colombiano, la organización secundada por Gaitán se veía obligada a marcar constantes sus propias particularidades. Cabe recordar que el movimiento comunista recorrió en este período una tumultuosa parábola: después de años de frustración y violencia electoral, sectores provenientes

lidado- es una cuestión meramente "anecdótica”, pues la UNIR habría participado del juego electoral en un par de ocasiones. Este reparo, sin embargo, no hace más que hiperbolizar la Realpolitik como la resolución de tensiones y, en consecuencia, permite explicar el fin del unirismo en 1935 como una mera reacción racional de sus dirigentes frente a los pésimos desempeños electorales. Esta postura, que le indilgaría a nuestro trabajo cierto simplismo analítico, oblitera la discusión identitaria, las tensiones internas y, precisamente, la heterogeneidad al interior del campo de afinidades unirista, cuestión que problematiza cómo ha sido entendido el devenir del unirismo y brinda nuevas luces a la -para nosotros- no tan autoevidente Realpolitik. Dicho con otras palabras: aquel tipo de críticas deploran de realizar un análisis teóricamente informado de los procesos sociopolíticos, asumiendo que lo que sucedió "en realidad" prescinde de ser pensado desde enfoques analíticos diversos. La idea de "mirada informada teóricamente" la tomamos del trabajo de Nicolás Azzolini y Sebastián Giménez, "Introducción”, en: Identidades políticas y democracia en la Argentina del siglo XX (Buenos Aires: Teseo, 2019), 9.

${ }^{50}$ Citado por López Giraldo, El apóstol desnudo, 73. 
tanto de la izquierda liberal como del viejo PS de 1919 crearon el PSR en 1926, el cual pasaría a llamarse Partido Comunista en julio de $1930 .^{51}$ En la declaración programática de este último se señalaba que el Partido lucharía por una "revolución cuyas fuerzas motrices serían el proletariado en primer lugar, el campesinado y otros sectores de la pequeña burguesía urbana y rural” ${ }^{52}$ Esto significó que, pese a la preocupación de tradición marxista por los obreros fabriles, en la Colombia de la primera mitad de los años treinta del siglo XX las problemáticas sociales más difundidas provenían del mundo agrario, por lo cual el PCC jugó un rol importante en las luchas campesinas del país. ${ }^{53}$ Es a partir de esta preocupación por el mundo rural que la doctrina del PCC empieza a difundirse desde las "ligas campesinas", agrupaciones gremiales de pequeños propietarios y arrendatarios que se popularizaron en el país entre $1930 \mathrm{y}$ $1935 .^{54}$ Esta preocupación del PCC por el mundo rural no entraba en tensión solamente con los postulados de la Komintern y del marxismo mismo -al no darle total prelación al proletariado fabril en tanto sujeto revolucionario-sino que también, era un entorno de disputa política con otras organizaciones populares. $^{55}$

De tal manera, La UNIR y el PCC establecieron una lucha constante por mantener el control y de sus bases y ganar terreno organizativo de los trabajadores agrarios. En consecuencia, no es de extrañar que se establecieran, desde cada organización, rasgos de diferenciación entre ambas que reafirmaban sus identidades políticas ${ }^{56}$. Así pues, resultó inevitable que la UNIR fuese,

51 John Green, Gaitanismo, liberalismo de izquierda y movilización popular (Medellín: EAFIT, 2013), 59. Sobre el devenir del PCC ver el ya citado libro de Medina, Historia del Partido Comunista.

52 Medina, “Los terceros partidos”, 276.

53 Sobre la cuestión agraria colombiana de la época ver: Gonzalo Sánchez, Las Ligas campesinas en Colombia. Auge y reflujo (Bogotá: Tiempo Presente, 1977), 19-20.

${ }^{54}$ Ana María Joven Bonelo, "El movimiento campesino en Cundinamarca. Una mirada desde la ideología y la cultura (1930-1946)" (Tesis de Maestría en Sociología, Universidad Nacional de Colombia, 2016), 52.

55 Sánchez, Las Ligas campesinas, 9. Según Medina y Joven Bonelo, tanto el Partido Agrario Nacional, uno de los primeros intentos de hacer una organización partidista genuinamente campesina, como la UNIR, tenían a los colonos como base importante de apoyo; incluso, existió una camaradería entre agraristas y uniristas: Medina, "Los terceros partidos", 284; Joven Bonelo, "El movimiento campesino", 81-82.

56 Se entienden aquí las identidades políticas como el conjunto de "prácticas sedimentadas, configuradoras de sentido", que establecen a través de un simultáneo proceso de "diferen- 
para los comunistas, la variante tropical de una organización fascista, pequeña burguesa y demagógica; y que, desde el unirismo, los valores insurreccionales pregonados por los comunistas fuera fuertemente rechazados.

\subsection{La revolución unirista}

Más allá de sus diferencias, resulta acertado, primero, ubicar tanto a la UNIR como al PCC dentro de lo que Gerardo Aboy Carlés denominó como "identidades populares". Estas son definidas por el autor argentino como:

[A]quel tipo de solidaridad política que emerge a partir de cierto proceso de articulación y homogeneización relativa de sectores que, planteándose como negativamente privilegiados en alguna dimensión de la vida comunitaria, constituyen un campo identitario común que se escinde del acatamiento sin más y la naturalización de un orden vigente ${ }^{57}$.

En consecuencia, resulta evidente que aquellas identidades son "populares" no tanto por una posición específica en el orden social sino porque su gramática de construcción identitaria remite a un proceso de construcción de un sujeto popular. ${ }^{58}$ Ciertamente, tanto uniristas como comunistas compartían una percepción del propio campo solidario como uno "negativamente privilegiado": tuviese el nombre de "proletariado", "campesinado" o "pueblo", el nosotros solidario de ambas agrupaciones tenían como referencia exterior la presencia de una alteridad ominosa, encarnada, por lo general, en una minoría expoliadora - de carácter nacional o internacional- que no sólo las subyugaba sino que, además, obtenía usufructo de su condición de desvalidos. Esta comunión identitaria de base, empero, no ensombrece las fuertes diferencias que se

ciación externa y de homogeneización interna” solidaridades estables, capaces de definir, a través de unidades de nominación, "orientaciones gregarias de la acción en relación a la definición de asuntos públicos". Así pues, toda identidad política "se constituye y transforma en el marco de la doble dimensión de una competencia entre las alteridades que componen el sistema y de la tensión con la tradición de la propia unidad de referencia”: Gerardo Aboy Carlés, Las dos fronteras de la democracia argentina. La reformulación de las identidades políticas de Alfonsín a Menem (Rosario: Homo Sapiens, 2001), 54. Las dimensiones de toda identidad política serían entonces: alteridad (un otro constitutivo), tradición (re-apropiación de la heredad) y representación (su carácter performativo).

${ }^{57}$ Gerardo Aboy Carlés, "De lo popular a lo populista o el incierto devenir de la plebs", en Las brechas del pueblo. Reflexiones sobre identidades populares y populismo, Gerardo Aboy Carlés, Sebastián Barros y Julián Melo (Los Polvorines: UNGS-UNDAM Ediciones, 2013), 21.

${ }^{58}$ Aboy Carlés, “De lo popular a lo populista o el incierto devenir de la plebs”, 21. 
establecieron entre la UNIR y PCC. Estas radicarían, entre muchas otras, en sus divergentes propuestas respecto a cómo llevar a cabo la revolución y, también, en lo referido al tratamiento de las alteridades políticas. ${ }^{59}$

La diferenciación propia respecto a estos distintos actores políticos quedaría plasmada en muchas de las páginas del semanario oficial de la experiencia unirista, cuyo primer número entraría en circulación en Bogotá a mediados de $1934 .{ }^{60}$ Efectivamente, en el primer número del periódico Unirismo, bajo la dirección de Gaitán y la supervisión de López Giraldo, la crítica al Partido Liberal en el poder no se hace esperar. En una nota titulada "Hoy como ayer" el postulado político era contundente: si en las primeras tres décadas del siglo XX el liberalismo había logrado acumular las fuerzas suficientes para ganar las elecciones en 1930, el gobierno liberal de Olaya Herrera no hacía honor a la "concepción que había servido de impulso y fuego para la conquista del poder" ${ }^{61}$ En una búsqueda constante por fundamentar su existencia en tanto organización política nueva -por fuera de las filas tradicionales de azules y rojos--, se resaltaba sin cesar que la llegada del Partido Liberal al poder en 1930 no implicó un cambio significativo para el establishment colombiano. Asimismo, es evidente que esta concepción particular de una continuidad de régimen no hubiera tenido sostén alguno sin postular, en primer lugar, una igualdad entre los partidos tradicionales; de allí que el gobierno de Olaya Herrera fuese constantemente devaluado como "conservador".

Esta equiparación entre partidos es importante de ser destacada aquí, más allá de las distintas discusiones sobre si efectivamente existían o no diferencias

${ }^{59}$ Este tratamiento de la alteridad remite a la intensidad que le imprime cada agrupación a su "principio de escisión", o sea, a posible inclusión o expulsión de los adversarios su campo identitario. El "principio de escisión” no es el mismo para todas las identidades populares; por ejemplo, algunas prefieren reforzar su particularismo -por lo general étnico, racial o subnacional-; otras, en cambio, pretenden transformar hegemónicamente o de manera violenta - esto es, eliminando físicamente a sus adversarios- toda la comunidad política: Aboy Carlés, "De lo popular a lo populista o el incierto devenir de la plebs", 24.

${ }^{60}$ Cabe agregar que durante su existencia la UNIR tuvo al menos cinco periódicos adeptos fuera de Bogotá, entre ellos, el antes mencionado Pluma Libre, de Pereira, dirigido por Célimo García Bustamante. Medina, "Los terceros partidos”, 281; Charry-Joya, “Unirismo y Pluma Libre”,79-80 Aquí se analiza sólo la publicación de Bogotá, aunque es importante destacar que la presencia de telegramas provenientes de distintas regiones de Colombia en Unirismo permitirían inferir que la lectura de este semanario no era exclusiva del público bogotano.

${ }^{61}$ Unirismo, Bogotá, 14 de junio de 1934, 3. 
entre azules y rojos durante la República Liberal. ${ }^{62}$ Para el unirismo, como actor de la época, el bipartidismo no era más que una coalición de sectores dominantes. Al respecto, se puede leer en Unirismo: "los partidos han perdido su contenido ideológico [...]. Lo ha reemplazado el sentimiento heredado, fuerza sin rumbo". ${ }^{33}$ De igual manera, que la alteridad de la UNIR tuviera su encarnadura tanto en los liberales - en el poder-como en los conservadores, demostraba el nivel de impugnación al orden esgrimido por la agrupación de Gaitán. Al respecto, un mensaje de adhesión publicado el 19 de julio de 1934 en Unirismo, afirmaba lo siguiente: "[l]lamamos la atención de una manera cordial a todos los trabajadores colombianos, [para] que abandonen de una vez [y] para siempre la mascarada política, rojo, azul, en la que nos han tenido por espacio de ciento diez años explotando nuestra fe y nuestro patriotismo, sin que hasta hoy haya alumbrado para nosotros el sol de la redención. ${ }^{64}$ Por último, el recurrente columnista de Unirismo, Efe Restrepo Ese ${ }^{65}$ consideraba que la elección del jefe conservador Laureano Gómez a la presidencia del Senado había sido "el primer hecho sintomático de la unión táctica de las derechas liberal y conservadora alrededor de los principios que les son comunes y sobre los cuales descansa el orden dentro del cual la mayoría trabaja para no vivir y la minoría vive para no trabajar". ${ }^{66}$

Esta recurrente referencia a un pequeño grupo que negocia en su interior para sostener un sistema injusto sugiere, para Daniel Pécaut, la presencia de

${ }^{62}$ Sobre esta discusión ver el sugestivo artículo de Francisco Gutiérrez Sanín, Juan Manuel Viatela y Tatiana Acevedo, “¿Olivos y aceitunas?? Los partidos políticos colombianos y sus bases sociales en la primera mitad del siglo XX”, Análisis Político 62: (2008): 3-24.

${ }^{63}$ Unirismo, Bogotá, 5 de julio de 1934, 3.

${ }^{64}$ Unirismo, Bogotá, 19 de julio de 1934, 7.

${ }^{65}$ Efe Restrepo Ese, oriundo de Armenia (actual departamento del Quindío) y cuyo nombre completo se desconoce, fue un personaje vital y recurrente en las editoriales de Unirismo, además de mantener un fluido diálogo epistolar con Gaitán. Para John Green, "Efe Restrepo Ese" hacía parte de una serie de militantes "populares" del movimiento que le escribían a Gaitán con propias y genuinas preocupaciones políticas: Green, Gaitanismo, liberalismo, 136. Para los fines de Green, que un intelectual del Unirismo sea descrito como un personaje plebeyo probaría - en el gaitanismo- la existencia de cierta autonomía de los "sectores populares" frente a las estrategias políticas de sus líder. Creemos, sin embargo, que estos gestos argumentativos de Green al interior de su impecable trabajo, antes de contrarrestar las posturas más denigratorias sobre el gaitanismo, evidencian su fuerte carga apologética.

${ }^{66}$ Unirismo, Bogotá, 26 de julio de 1934, 3. 
“ciertos acentos marxistas" en el lenguaje usado por los uniristas ${ }^{67}$ A propósito de esto, en una nota de Unirismo de junio de 1934, se considera que la existencia misma de la organización es prueba suficiente para demostrar que en Colombia "ha ocurrido 'algo' que ha empujado su historia por los caminos de la lucha de clase" y que, por consiguiente, "las clases explotadas se polarizan hacia el Unirismo como única bandera de reivindicaciones proletarias". ${ }^{68}$ Pese a lo anterior, Pécaut sostiene que la organización unirista se diferenciaba de la comunista al enarbolar una contradicción, la cual consistía en usar la gramática marxista para caracterizar un antagonismo y, a su vez, atenuar su imprecación usando "otro tono" alejado del clasista, esto es, no apelar explícitamente a la lucha de clases. Para el autor francés, entonces, se difuminaba desde la UNIR un eventual enfrentamiento entre proletarios y capitalistas. ${ }^{69}$ En contraste, John Green considera que durante la primera mitad de la década de 1930 el unirismo y los comunistas competían por una movilización política que terminaría siendo capitalizada por el Partido Liberal durante las reformas del gobierno de López Pumarejo. Antes de este desenlace, sin embargo, la diferencia entre la UNIR y sus "hermanos" comunistas no radicaba, como lo considera Pécaut, en el uso de la gramática marxista como tal sino en que Gaitán representaba la "culminación" de una tradición de izquierda liberal de movilización popular, la cual había permeado la historia colombiana desde las luchas independentistas. Con lo anterior Green concluye que, para la época del nacimiento del unirismo, el comunismo carecía todavía de cualquier posibilidad de arraigo popular. ${ }^{70}$

Lo cierto es que, al igual que lo pregonado por el comunismo colombiano, desde la UNIR la idea de revolución se colocaba en el lugar de la "necesidad histórica”. Como lo recuerda Hannah Arendt, en la edad moderna la idea de revolución conservó ciertos visos que remitían a su connotación original; es decir, como "irresistibilidad" astronómica y como "movimiento rotatorio de las estrellas" que siguen "un camino predestinado y es ajeno a toda influencia del poder humano" ${ }^{71}$ En este sentido, desde las intervenciones de los uniristas, la idea de estar representando un tramo más en el largo pero inevitable camino

${ }^{67}$ Daniel Pécaut, Orden y violencia. Evolución socio-política de Colombia entre 1930-1953 (Bogotá: Norma, 2001), 239.

${ }^{68}$ Unirismo, Bogotá, 14 de junio de 1934, 8.

${ }^{69}$ Pécaut, Orden y violencia, 240-241.

${ }^{70}$ John Green, "Sibling Rivalry on the Left and Labor Struggles in Colombia during the 1940s", Latin American Research Review: 35, n. ${ }^{\circ} 1$ (2000): 86.

${ }^{71}$ Hannah Arendt, Sobre la revolución (Madrid: Alianza, 2006), 62. 
hacia la revolución tiene un lugar superlativo. El unirismo se concibe a sí mismo como parte de un "impulso revolucionario que dirige la necesidad histórica de un permanente progreso" y como parte fundamental para "posibilitar el tránsito hacia un Estado socialista ideal que la humanidad coronará”. ${ }^{72}$ En esta gramática teleológica, entonces, desde la UNIR se afirmaba: "[t]enemos plena conciencia que los uniristas representan apenas una etapa [...], un ciclo que no será el último en el avance revolucionario del país"; una etapa que ha consistido en "iniciar el despertar de las conciencias de las verdaderas fuerzas productoras" por medio de ideas con "acervo de verdades sólidas que sustentan la imprescindible necesidad del abandono del individualismo, de la política de casta". ${ }^{73}$

Ahora bien, volviendo a lo sugerido por Pécaut -los "acentos marxistas" de la UNIR-, consideramos aquí que no es sólo que el unirismo haya usado "otro tono" alejado de una lucha clasista, sino que, además, puso en tensión los supuestos revolucionarios que circulaban en su tiempo, en especial los provenientes del comunismo colombiano. Los uniristas, de hecho, no se mostrarían totalmente reacios a disputar el poder del Estado a través de las urnas. Pero su significación era particular: muchos de ellos empezarían a considerar a la disputa electoral como una etapa natural de la acción revolucionaria. Desde su creación, la UNIR sostuvo una relación tensa, de crítica pero también de respeto, hacia las reglas de juego establecidas por el sistema político, como se puede evidenciar en su participación en algunos comicios. Según César Augusto Ayala Diago, "[s] u primera salida en grande [de la UNIR] se dio a raíz de las elecciones para concejales del primero de octubre de 1933 "74. Asimismo, según las páginas de Unirismo, antes de "pasar a la etapa [...] revolucionaria, de transformación social”, era preciso primero establecer una "etapa inmediata de reformas o periodo reformista (parcelación, limitación de la propiedad por el Estado, tecnicación [sic])", ya que no se podía obtener

72 Unirismo Bogotá, 28 de junio de 1934, 3 y 23 de agosto de 1934, 3.

${ }^{73}$ Unirismo [Bogotá], 12 y 19 de julio de 1934, 3 - la misma página en ambos números.

${ }^{74}$ Ayala Diago, "La UNIR: entre Gaitán y los gaitanistas", 109. Es importante aclarar que dicha participación electoral estaría secundada por la represión de uniristas en distintas partes de la geografía colombiana por parte del gobierno liberal; por ejemplo, la represión del 4 de febrero de 1934, en Fusagasugá (Cundinamarca), en la cual la policía asesinó a varios campesinos uniristas, se convertiría en un hito de la agrupación. Sin lugar a dudas, el ataque físico por parte de las fuerzas del orden, bajo control del oficialismo liberal, reforzaría la animadversión contra el partido en el poder como la expresada por López Giraldo, El apóstol desnudo, 77-91. 
dichas reformas desde el "Estado como está constituido". Para tales fines, los sectores populares tenían la obligación de imponer las transformaciones más urgentes "por medio de sus representantes auténticos en los cuerpos legislativos [...] mientras llega la hora del derrocamiento del sistema vigente y el establecimiento y consolidación del gobierno de las clases productoras". ${ }^{75}$ En este mismo sentido, el columnista unirista Efe Restrepo Ese afirmaba que:

La concepción del Estado para la etapa que aspiramos a realizar los actuales militantes uniristas, es [...] la de un Estado intervencionista y organizador de la economía, pero no inspirándose en el interés de la minoría parasitaria, [...] cuya eliminación como clase será precisamente uno de los fines que se coronarán en la siguiente etapa, cuando a la sociedad se le tracen perfiles socialistas bajo la dictadura de la democracia obrero-campesina, cuyo advenimiento facilitará el unirismo. ${ }^{76}$

A partir de esta concepción del rol del Estado para la UNIR, en voz del columnista Restrepo Ese, la revolución se iría concretando progresivamente. De allí que la inmediatez del actuar del Partido Comunista fuera considerada como una práctica de "agitadores y frenéticos e infantilistas que piensan ahistóricamente, sentados en tesis propias para la realidad colombiana y continental del año 2,000" ${ }^{77}$ Es más, desde el unirismo se califica los comunistas como "simples teorizantes "extremistas" que "no actúan en el verdadero campo de los hechos sino [que,] indigestos de fraseología revolucionaria, se concretan [sic] únicamente a criticar, situándose precisamente en el campo de la reacción". 78

75 Unirismo, Bogotá, 14 de junio de 1934, 12 - el resaltado es nuestro.

${ }^{76}$ Unirismo, Bogotá, 23 de agosto de 1934, 3 - el resaltado es nuestro.

77 Unirismo, Bogotá, 23 de agosto de 1934, 3.

${ }^{78}$ Unirismo, Bogotá, 23 de agosto de 1934, 5. En sus reflexiones sobre "el problema de la revolución en el pensamiento gaitanista”, Antonio García considerará-varias décadas después de la experiencia unirista-, que esta concepción de la revolución remitía a una aceptación por parte de Gaitán del reformismo como único medio para transformar su país; cuestión que, en definitiva, marcaba el "triunfo doctrinario" del abogado sobre el político. En todo caso, García destaca esta tensión en los siguientes términos: "['Gaitán] [n]o era un reformista-en el sentido de que sólo viese reformas y no aspirase a transformar la totalidad del sistema de vida- sino un revolucionario, en su mentalidad y en su temperamento, en su sensibilidad y en su voluntad, que creyó en la validez de las tácticas reformistas, como medio general y exclusivo para llegar a la Tierra Prometida": Antonio García, Gaitán y el camino de la revolución colombiana (Bogotá: Ediciones Camilo/CEDIS, 1974), 146. 
En relación a la inevitabilidad de la revolución, es importante destacar que la organización unirista recurría a una caracterización doble del pueblo colombiano para reafirmar su rol vanguardista. Por una parte, en las páginas de Unirismo, la masa-pueblo es el sujeto revolucionario autónomo, que acompañaba al movimiento porque ha resuelto él mismo llevar a cabo "el cambio substancial, completo [...], ante todo, desde el punto de vista económico"; cambio que solo es posible constituyendo una empresa política que ponga al descubierto que la cúpula de representantes tradicionales está integrada por "banqueros latifundistas, republicanos jugados, diplomáticos trashumanantes [sic]" y por los liberales en el poder, estos últimos "traidores a los ideales de izquierda" y que "no tienen ideas que los diferencien de los conservadores". ${ }^{79}$ Por otra parte, sin embargo, es llamativo que en un importante documento de la UNIR como lo fue su "Plataforma de acción" ${ }^{80}$ el jefe unirista expusiera otra figura del pueblo colombiano y que entraba en tensión con aquella antes esbozada.

Ciertamente, este otro pueblo no sería aquel resuelto a cambiar su destino por motu proprio sino, más bien, un conglomerado primitivo del cual no se puede esperar nada, muchos menos su apoyo electoral. En la "plataforma de acción” unirista ${ }^{81}$, Gaitán afirmaba:

Quien desee en este país realizar la inmensa, trascendental y al parecer casi imposible obra de incorporar a nuestro pueblo, a nuestras masas, las cuales viven hoy en el más absoluto primitivismo en lo material, cultural y moral, no puede ni debe engañarse en cuanto al apoyo que ellas le presten. $\mathrm{Ni}$ tienen conciencia de sus destinos, ni hay razones para que la tengan [...].

${ }^{79}$ Unirismo, Bogotá, 28 de junio de 1934, 3.

${ }^{80}$ Este documento es el resultado de una extensa entrevista concedió Gaitán al periódico El Espectador en agosto de 1934 y que después tomará por título "Plataforma de acción de la UNIR".

${ }^{81}$ Para Luz Ángela Núñez, que esta "plataforma” haya surgido en forma de reportaje en prensa y no en forma de programa o manifiesto da muestra del "carácter caudillista" de la UNIR" y, por ende, de una ausencia de una estructura “ideológica definida”: Luz Ángela Núñez, "Marxistas, liberales y antifascistas. Configuración de una izquierda en Colombia (1930-1951)” (Tesis doctoral en Historia, Universidad de los Andes, 2014), 83. Nuestro trabajo destaca dicha debilidad ideológica no sólo por el rol de Gaitán sino por la tensión ambigua respecto al Partido Liberal; este rasgo nos parece constitutivo de las tensiones internas del unirismo y que repercutió en su débil participación en la contienda electoral. Dicho en otros términos: no parecería acertado afirmar que la efectiva -aunque pobre- participación electoral del unirismo puso en suspenso sus tensiones internas. 
Nuestras masas en lo político no tienen un sentido distinto del fonético. El 'viva' al partido conservador o al partido liberal. ${ }^{82}$

Esta la lectura pesimista del rol que cumple el pueblo colombiano en la transformación política le permite a la organización unirista considerar que un "gobierno para el pueblo" significaría exclusivamente la constitución de "una minoría que no necesitándolo estrictamente [al pueblo], dedique su actividad, que debe tener mucho sacrificio, a liberar a la gran mayoría, en la cual por principio puede que no encuentre colaboración, sino antes resistencia" ${ }^{83} \mathrm{La}$ minoría conductora del pueblo que propone el unirismo sería entonces una de tipo vanguardista: un órgano que es parte pero que, a su vez, está más allá del pueblo, otorgándole eventualmente conciencia a este último. Como es sabido, la idea misma de vanguardia planteada por Lenin es expuesta en su ampliamente difundido “¿Qué hacer?” de 1902. Allí, el autor asegura que la conciencia política solo se le puede aportar a los sectores obreros "desde el exterior", es decir, desde un cuerpo de revolucionarios profesionales a la cabeza del partido del proletariado: "[s]olo el partido que organice campañas de denuncias que realmente interesen a todo el pueblo podrá convertirse en nuestros días en vanguardia de las fuerzas revolucionarias" ${ }^{84}$ La tajante separación entre órgano vanguardista y las demás organizaciones para "el gran público", propuesta por Lenin, tiene como corolario la exaltación del primero; la vanguardia sería cardinal para el proyecto revolucionario leninista en tanto estaría compuesta por revolucionarios ya formados, "profesionales", conscientes de los verdaderos intereses del proletariado.

Ahora bien: si tanto Lenin como el unirismo de Gaitán parecen coincidir en el rol imprescindible de la vanguardia para la transformación política radical, la idea de revolución que inspiró la insurrección rusa de 1917 es distinta a la pregonada por la UNIR en 1934. En sus reflexiones sobre la Revolución de Octubre, León Trotsky consideraba que “en los momentos decisivos, cuando el orden establecido se hace insoportable para las masas, éstas rompen las barreras que las separan de la palestra política [...]. La historia de las revoluciones es para nosotros, por encima de todo, la historia de la irrupción violenta de las masas

${ }^{82}$ Unirismo, Bogotá, 23 de agosto de 1934, 9.

83 Unirismo [Bogotá], 23 de agosto de 1934, 9-10.

${ }^{84}$ Vladimir Ilich Lenin, ¿¿Qué hacer?” en Obras completas (Madrid: Akal, 1976), Tomo V, 439 - las cursivas son del original. 
en el gobierno de sus propios destinos" ${ }^{85}$ En contraste con esta "irrupción violenta" descrita por Trotsky, la labor revolucionaria propugnada por el unirismo consistía en "lograr dentro de la realidad [...] una etapa de aminoración o debilitamiento de las fuerzas que detienen el progreso ideológico total"; el cumplimiento de esta etapa "[p]uede que no sea revolucionario dentro de una concepción integral, pero lo es en el momento y circunstancias en que actúa como útil y necesaria etapa" ${ }^{86}$

Efectivamente, reconociendo ser ajenos a una "concepción integral" de la revolución -similar a la de Trotsky, por ejemplo-, la UNIR buscó marcar distancia frente a los sectores políticos comunistas y su concepción del accionar revolucionario como tal. De vuelta: Ambas agrupaciones -PCC y UNIRcompartían una idea particular de vanguardia, pero el unirismo se distancia de los comunistas precisamente en la manera de implementar la transformación política. De esta manera criticaba Gaitán la estrategia comunista:

Ya sé que la fórmula extremista, casi siempre retórica y nada más, no advierte [...] sino el encuentro catastrófico y violento que se decida en vencedores y vencidos, en una batalla inmediata y total. Nosotros pensamos de muy diverso modo. [...] Estamos muy lejos del sarampión extremista sin reflexión y sin método, que piensa de la noche a la mañana convertirnos al comunismo o al socialismo. No somos enemigos de la riqueza sino de la pobreza. ${ }^{87}$

Por lo tanto, y en concordancia con esta caracterización de la revolución, que no recurre al "sarampión del extremismo", la acción revolucionaria de la UNIR no iría acompañada de un llamado explícito a la toma violenta del poder. Para decirlo de otro modo: los sentidos de la revolución en el unirismo tienen que ver más con la sinuosa construcción de una fuerza crítica al bipartidismo que con un proyecto de usurpación del poder a las "castas" bipartidistas a través de su eliminación violenta.

${ }^{85}$ León Trotsky, Historia de la Revolución Rusa (Buenos Aires: RyR, 2007), 19 - el resaltado es nuestro.

${ }^{86}$ Unirismo, Bogotá, 23 de agosto de 1934, 10 y 12 \ el resaltado es nuestro.

${ }^{87}$ Unirismo, Bogotá, 23 de agosto de 1934, 10 y 12. 


\subsection{Revolución y evolución en el unirismo}

El llamamiento a la "destrucción implacable de todo lo que se oponga a la emancipación de los trabajadores" ${ }^{88}$ pero sin recurrir a la eliminación física de quienes lo mantienen vigente, ha sido entendido por diversos analistas como el rasgo que atravesaría de inicio a fin la carrera política de Gaitán y de su movimiento como tal. Es decir: una posición elusiva respecto a la realización de la revolución y, en contraste, una reivindicación de la transformación evolutiva del cuerpo social.

Ahora bien, si el sentido moderno de la palabra revolución fue fijado en la Revolución Francesa de 1789 y tiene tres elementos esenciales, a saber, "la destrucción de un viejo orden, construcción de uno nuevo y medios violentos para realizar lo primero" ${ }^{89}$ según Jiménez Panesso el vocablo evolución "adquirió un significado de orden nuevo que se construye gradualmente, por medios pacíficos y legales"; de tal manera, la diferenciación entre evolución y revolución resulta "fundamental en la historia de los movimientos socialistas, para distinguir entre socialismos revolucionarios y socialismos reformistas" ${ }^{90} \mathrm{Al}$ respecto, sin embargo, el unirismo logra poner en cuestión la posibilidad misma de realizar la distinción revolución/evolución - en apariencia transparente. ¿Qué sucede, pues, con aquellos procesos políticos cuya construcción identitaria tiene como base los "medios pacíficos y legales" y que, a su vez, se atribuyen un rol implacablemente revolucionario? El quid de esta cuestión, como ya se ha mencionado anteriormente, no es atribuirnos, en tanto analistas, la potestad para decir qué es o no revolucionario, sino de dilucidar qué sentidos tiene la revolución en experiencias políticas concretas.

Es importante aquí recordar que, por ejemplo, para Gonzalo Sánchez la "revolución" que predicaba Gaitán - "y con toda razón”, agrega el autor- era comprendida por los comunistas colombianos como una que no planteaba el problema crucial de todo proceso político revolucionario: la toma del poder. En ese sentido, afirma Sánchez que "la solución Unirista, bien en su fórmula redistributiva, o en la de las cooperativas intervenidas estatalmente, se inscribe dentro de los marcos del sistema socio-económico vigente”; en este sentido, dice el autor, el unirismo "reflejaba, por sobre todo, los intereses de la pequeña burguesía. Su socialismo no pasa de ser, en realidad, un capitalismo de Estado

\footnotetext{
${ }^{88}$ Unirismo, Bogotá, 23 de agosto de 1934, 4.

89 Jiménez Panesso, "Revolución: imágenes, ideas, relatos", 392. Los elementos citados por el autor son tomados de las reflexiones de Raymond Williams.

90 Jiménez Panesso, "Revolución: imágenes, ideas, relatos”, 392.
} 
[...] Gaitán estaba, pues, más cerca del gradualismo de las social-democracias europeas, que de una posición auténticamente revolucionaria". ${ }^{91}$ Pese a lo anterior, las disquisiciones analíticas expuestas permiten concluir aquí que Sánchez realiza un análisis bastante acotado del unirismo. Para decirlo sin ambages: el historiador colombiano simplemente replica el diagnóstico otrora comunista respecto a la experiencia de la UNIR. Por ejemplo, en una editorial de El Bolchevique -órgano periodístico del Partido Comunista- de septiembre de 1934, el unirismo es caracterizado como una herramienta desestabilizante del proletariado bajo la tutela del Partido Liberal; la UNIR, por ende, no sería más que un movimiento demagógico y fascista. Ya para 1935, el medio gráfico del comunismo colombiano decía sin tapujos: "[e]l principal enemigo del proletariado [...] es el partido liberal, sobre todo su izquierda y dentro de su izquierda la variedad fascistizante rotulada unirismo".92

A su vez, la llegada del segundo gobierno de la República Liberal a mediados de 1934, bajo el mando de Alfonso López Pumarejo y su "Revolución en Marcha”, sumaría aún más tensiones a la ya fuertemente disputada concepción de la revolución en la época. El reciente arribo de López al Poder Ejecutivo, en efecto, significó para la solidaridad unirista el advenimiento de una engañosa propuesta revolucionaria para el pueblo. En octubre de 1934, apenas dos meses después de la posesión del nuevo presidente, se afirmaba en Unirismo: "[s]e sigue aun hablando de revolución, semanalmente se pronuncian discursos", y sin embargo, "[l]a estructura conservadora de la república se mantiene en toda su integridad. Desde la Constitución de la República [de 1886], [...] hasta la instrucción pública, todo permanece intacto, todo sigue el mismo curso, todo ofrece la misma deplorable situación”. ${ }^{33}$ Además, agregarían los uniristas, el gobierno de López solo podría proceder así en Colombia ya que "hay un pueblo sordo y unos usufructuarios [...] demagogos", estos últimos "coreados,

${ }^{91}$ Sánchez, Las Ligas campesinas, 79-80 -el resaltado es nuestro. De igual manera, para Braun el sueño de Gaitán era construir "un capitalismo desde abajo, una sociedad de individuos meritorios, de trabajo arduo y pequeña propiedad fundamentada en la familia”: Braun, Mataron a Gaitán, 65 y 99. Esta crítica apunta a caracterizar a Gaitán como un personaje "pequeño burgués", ergo, un falso socialista.

92 Joven Bonelo, "El movimiento campesino", 54; El Bolchevique citado en Álvaro Tirado Mejía, "López Pumarejo: La Revolución en Marcha”, en Nueva Historia de Colombia, ed. Álvaro Tirado Mejía, Volumen II (Bogotá: Planeta, 1989), 311.

${ }^{93}$ Unirismo, Bogotá, 11 de octubre de 1934, 3. 
defendidos y aplaudidos por los mismos siervos a quienes parece que en vano se les quiere iniciar en el sendero del conocimiento". ${ }^{94}$

\subsection{La fugacidad de la UNIR}

Pese a que Gaitán reiteraba desde fines de 1934 que las contiendas electorales eran algo secundario para la UNIR, las elecciones para las Asambleas Departamentales (del 5 de mayo) y la Cámara de representantes (del 26 de mayo) en 1935 serían tomadas por distintos miembros de la organización como una prueba para medir su capacidad de convocatoria, esto teniendo en cuenta la ya establecida abstención electoral del Partido Conservador. Ciertamente, en la Convención Unirista de abril de 1935, Gaitán expuso su punto de vista frente a la participación de la agrupación en las elecciones del siguiente mes. Según el jefe de la UNIR, "vamos ahora sí a saber en concreto de qué son capaces las fuerzas de izquierda" ${ }^{95}$ En contraste con lo anterior, sin embargo, una semana después de la Convención Gaitán declaraba que la agrupación debería no participar en la contienda electoral: "[p]ersonalmente soy partidario de la abstención, pues son varias las autoridades [...] que no le ofrecen al Unirismo ninguna clase de garantías". ${ }^{96}$ Así pues, para mayo de 1935 , la posición de la UNIR frente a las elecciones y al Partido Liberal resultaba a todas luces confusa. En contradicción con la negativa del jefe de la UNIR, se pueden encontrar en la primera plana de varios números de Unirismo el listado de los candidatos a la "próxima asamblea" por Bogotá, siendo cabeza de lista Jorge Eliécer Gaitán. ${ }^{97}$ Pese a esto, en las elecciones del 5 de mayo, el poder de representatividad de la UNIR sería puesto fuertemente en cuestión: en todo el país el unirismo obtuvo 3.799 votos frente a los 477.361 del oficialismo liberal. ${ }^{98}$

Por su parte, las elecciones del 26 de mayo de 1935 tendrían un componente sorpresa: Gaitán no participaría en ellas bajo la rúbrica unirista sino bajo el

${ }^{94}$ Unirismo, Bogotá, 18 de octubre de 1934, 3. Esta incapacidad del pueblo, al margen de la civilización, tiene también - para Gaitán y los uniristas- razones fisiológicas, referidas a la salud y a la higiene. Su insistencia frente a la salubridad llevó a que los opositores de la UNIR consideraran despectivamente que esta organización pretendía realizar una "Revolución del jabón”: Green, Gaitanismo, liberalismo, 175.

95 Unirismo, Bogotá, 13 de abril de 1935, 2.

${ }^{96}$ Unirismo, Bogotá, 25 de abril de 1935, 2

${ }^{97}$ Unirismo, Bogotá, 4 de mayo de 1935, 1.

98 Tirado Mejía, “López Pumarejo”, 310. El PCC, por su parte, consiguió 1.780 votos y la agrupación de los sectores más acaudalados del país, la Acción Patriótica Económica Nacional (APEN), obtendría solo 850 votos. 
patrocinio del Partido Liberal. ¿Cómo era posible este regreso al oficialismo liberal por parte del jefe de la UNIR? ¿Cómo retornar al partido que, según la trayectoria discursiva del unirismo, representaba tanto la continuidad del régimen conservador como una de las alteridades centrales de la organización? Sobre estos interrogantes, la narración de López Giraldo inspiró, sin duda, una respuesta común frente al accionar de Gaitán: el ambiguo jefe de la UNIR había decidido disolver la organización. Para el autor de El apóstol desnudo, ciertamente, el comportamiento errático y las evasivas decisiones del jefe unirista frente a las elecciones "hizo imposible una organización eficaz a nuestras huestes". ${ }^{99}$ No obstante ello, la decisión del jefe unirista fue menos arbitraria, o al menos fue tomada con el consentimiento de otros miembros de la organización; incluso, la Directiva Departamental Unirista redactaría una declaración oficial respaldando la candidatura de Gaitán en las listas del liberalismo. De tal manera, tres días antes de los comicios del 26 de mayo de 1935, la primera plana de Unirismo tenía como encabezado: "Jorge Eliécer Gaitán defenderá en el Congreso los programas Revolucionarios de la UNIR", seguido de una entrevista a su jefe. Allí Gaitán afirmaba que el unirismo estaba de acuerdo con su candidatura desde el Partido Liberal, "a excepción de dos o tres voces aisladas que no han tenido ninguna repercusión”; aclaraba, además, que "tal candidatura no implica ningún compromiso de mi parte [;] lo han hecho [respaldar su candidatura] para que en el parlamento defienda como defenderé mis puntos de vista". ${ }^{100}$ Finalmente, en forma de cierre del reportaje, el jefe unirista agregó: "[n]uestra organización no solo no se liquidará, sino que va a entrar en un periodo de mejor organización interna [...]. Si ella ha sido capaz de resistir no solo los embates de fuera, sino especialmente los de dentro, menos ha de flaquear ahora cuando su porvenir ideológico es más halagüeño que nunca. ${ }^{101}$

En cuanto a este secuencia de hechos, muchas editoriales de Unirismo no solo reiteraron la ausencia de compromisos políticos de Gaitán con el Partido Liberal, sino que también buscaron desarmar el fuerte antagonismo que habían establecido con el partido oficialista. Para el importante columnista Efe Restrepo Ese, el respaldo de la Directiva Departamental de la UNIR a Gaitán era coherentemente revolucionario, y esto por varios motivos:

\footnotetext{
99 López Giraldo, El apóstol desnudo, 124.

${ }^{100}$ Unirismo, Bogotá, 23 de mayo de 1935, 1.

${ }^{101}$ Unirismo, Bogotá, 23 de mayo de 1935, 8.
} 
Nosotros creemos, y honradamente confesamos, que en el seno del partido liberal existen todavía posibilidades revolucionarias y que es un deber de los revolucionarios sinceros y sin prejuicios sectarios o bibliográficos, contribuir al desarrollo de tales posibilidades y encauzarlas al aceleramiento del proceso material y psicológico [...] [Q]uienes censuran a Gaitán por la aceptación de su candidatura en la plancha liberal [...] se me aparecen como hombres de mirada deficiente, incapaz de descubrir el horizonte teórico ni los cambios históricos que conducen a la Revolución. ${ }^{102}$

Así pues, el regreso del jefe del unirismo a las filas liberales fue interpretado como una inclusión de las fuerzas revolucionarias dentro del orden; un orden, es cierto, que hasta ese momento había sido descrito como uno que tendía a "conservatizarse". De todos modos, la torsión del antagonismo estaba consumada: desde Unirismo el retorno de Gaitán a las huestes del Partido Liberal no era descrito como una traición a la UNIR sino, más bien, una parte integral de la estrategia revolucionaria.

Este regreso del jefe unirista al Partido Liberal - en cabeza del gobierno de López Pumarejo--, significó, principalmente, que la alteridad del unirismo perdiera la ambigua entidad que tenía: una figura más o menos compacta, compuesta por los miembros de un sistema conservador provenientes de ambos partidos, hacía agua completamente. Desactivado por completo su antagonismo principal, la alineación con el gobierno de la Revolución en Marcha se hizo inevitable, marcando con esto el ocaso definitivo de la UNIR ${ }^{103}$. Ya para octubre de 1935 la UNIR dejaba de ser una referencia importante en el escenario político colombiano. Distintos seguidores de Gaitán -y que lo acompañarían en sus empresas políticas de la década de 1940-permanecerían a su lado en su regreso al liberalismo. Otros uniristas, por su parte, vieron en el proceder de su jefe la afrenta de un traidor, "la negación del apostolado por parte del APOSTOL". ${ }^{104}$

${ }^{102}$ Unirismo, Bogotá, 23 de mayo de 1935, 3 y 7.

${ }^{103}$ Según el gaitanista José Antonio Osorio Lizarazo, las ideas más importantes de la UNIR fueron cooptadas por el nuevo gobierno de López, quien después "les introdujo modificaciones, las cercenó en parte y desconoció sistemáticamente la primordial paternidad de las mismas": José Antonio Osorio Lizarazo, Gaitán: vida, muerte y permanente presencia (Bogotá: El Áncora, 1998), 175. Para este reconocido gaitanista, el unirismo sería fagocitado por el Partido Liberal gracias a un estratagema de López Pumarejo.

${ }^{104}$ López Giraldo, El apóstol desnudo, 148 - las mayúsculas en el original. 


\section{Conclusiones}

Este trabajo pretendió dar muestra de que la UNIR, más que una organización rápidamente clasificable como socialista, fue un proyecto político construido sobre múltiples tensiones, y que aquí se han resaltado desde una particular forma de entender la revolución. Se destacó que la revolución misma no fue unívocay, por lo tanto, fue constantemente redefinida y disputada por múltiples organizaciones políticas de izquierda a mediados de la década de 1930 en Colombia. El propio Gaitán, desde mediados de la década de 1920 y en distintas intervenciones previas a 1933 venía esbozando una concepción particular de la acción revolucionaria a la colombiana. Frente a lo anterior, no hemos partido de definir unsentido de la revolución para así evaluar un proyecto político que entró en tensión con el bipartidismo tradicional. Antes bien, hemos hecho hincapié en cómo la UNIR entendía la acción revolucionaria al destacar los siguientes elementos: el rescate del "verdadero liberalismo" - mancillado por el Partido Liberal ya en el Poder Ejecutivo-, el establecimiento de una doble figuración del pueblo colombiano, tanto reivindicativa como denigratoria, que precisaba de una vanguardia implacable; $y$ finalmente, el procesamiento particular de la alteridad propuesta por la organización. ${ }^{105}$ Frente a esto último, se evidenció que el unirismo configuró primordialmente una otredad encarnada en una casta expoliadora de mote tanto conservador como liberal, configuración de la alteridad esta que, sin embargo, no se tradujo en una reivindicación de su eliminación física. De hecho, el rasgo que distingue a la UNIR del Partido Comunista de Colombia es el de cómo llevar a cabo la revolución. O dicho en otras palabras: si tanto los uniristas como comunistas compartían una concepción particular de la revolución, entendida como una transformación inevitable del poder político, el campo solidario de la UNIR consideraba que la acción revolucionaria podía llevarse a cabo solamente desde la acción de una

${ }^{105}$ Es importante no soslayar la fuerte presencia del déficit biológico atribuido al pueblo en la discursividad de Gaitán durante su devenir político. Lo anterior, según Adriana Rodríguez Franco y Gilberto Parada, era el corolario de una perspectiva netamente positivista de Gaitán, desde la cual la sociedad colombiana era un organismo cuyo bienestar biológico fortalecería su unidad política: Adriana Rodríguez Franco y Gilberto Parada, “Jorge Eliécer Gaitán y el positivismo: una construcción ideológica y jurídica”, Revista Goliardos: 11 (2006): 16. Para estos autores, aquel positivismo explicaría por qué "Gaitán no habló de una revolución" sino de un "proceso de evolución paralela a las condiciones del país" (p. 24). Si bien comulgamos respecto al hincapié que hacen estos autores sobre las nociones positivistas en la discursividad de aquel líder, en este trabajo ha quedado claro que, lejos de no hablar de la revolución, Gaitán era un actor más que \a mediados de los años treinta $₫$ disputaba las significaciones y las formas de la acción revolucionaria. 
vanguardia decidida instaurar la justicia social y abocada a imponer, en nombre del pueblo, a sus representantes a través de las elecciones.

Por otra parte, el regreso de Gaitán al Partido Liberal es comprensible sin tener que apelar a la ambición y al oportunismo de quien sería futuro Jefe único del liberalismo. ${ }^{106}$ En cambio, se ha destacado aquí un factor normalmente excluido del análisis sobre el unirismo: la labilidad de las fronteras identitarias que estableció el unirismo frente a sus alteridades, principalmente la encarnada por el liberalismo oficialista. Dicha labilidad, es cierto, se evidenció especialmente en dos momentos: primero, en la insistencia de Gaitán de no haber formado con la UNIR otro partido más sino una organización o fuerza revolucionaria -la cual se arrogaba la verdadera tradición insurreccional del Partido Liberal-. ${ }^{107}$; y, segundo, a través de las dubitativas decisiones que tuvo Gaitán y sus seguidores para impulsar al unirismo a una campaña electoral incisiva para mayo de 1935. Para decirlo en otros términos: en la UNIR no se había gestado un antagonismo rígido frente al oficialismo como para obstaculizar el retorno de Gaitán a su antiguo partido; y esto básicamente hace muy difícil referirse al unirismo como un intento articulado de "tercer partido" (como sí lo fue, en tanto alternativa al bipartidismo, el comunismo colombiano). ${ }^{108}$ Los uniristas no buscaron cristalizar el enfrentamiento entre dos polos irreductibles del espacio comunitario: es en este sentido que la

${ }^{106}$ Según Ayala Diago, la candidatura de Gaitán por el Partido Liberal en 1935 se debía a un motivo un tanto más evidente: López Pumarejo había advertido que Gaitán quería ser senador, "y nada mejor que ofrecerle al intrépido arribista esa posibilidad inmediata desde el liberalismo": Ayala Diago, "La UNIR: entre Gaitán y los gaitanistas", 109 - el resaltado es nuestro.

${ }^{107}$ Obviamente, con esto no se pretende afirmar que el poseer un rótulo partidista sea garantía de la permanencia en el tiempo de una experiencia política particular.

${ }^{108}$ Para Richard Sharpless, solo es posible entender el surgimiento del unirismo si se le considera como una organización que pretendió presionar desde afuera al Partido Liberal. Richard Sharpless, Gaitán of Colombia. A Political Biography (Pittsburgh: University of Pittsburgh Press, 1978), 83. Al igual que otros autores, Sharpless destaca también que el fin de la UNIR se explica por el oportunismo y realismo de Gaitán. La lectura del unirismo que aquí se plantea, sin embargo, considera empíricamente imposible y hasta analíticamente simplista asegurar cuáles fueron los “verdaderos” motivos de Gaitán para no continuar con este proyecto político. En nuestro caso, la labilidad del antagonismo con el liberalismo indica de por sí la precariedad identitaria de la UNIR y - pese a los distintos intentos organizativos, como lo resalta el trabajo de Charry-Joya- brinda luces acerca de su fugacidad. Dicho en otros términos, en este trabajo hemos establecido que la propuesta identitaria del unirismo era endeble ya desde sus propios inicios. 
UNIR no azuzó la eliminación física de su alteridad. Los pobres resultados electorales de mayo de 1935 y la fuerte presencia de la "Revolución en Marcha" de López Pumarejo en la política colombiana horadaban aún más cualquier viso de rigidez identitaria.

En todo caso, la excesiva labilidad identitaria que marcamos en la UNIR frente al Partido Liberal no fue aceptada por todos sus miembros, aun menos por los más radicalizados, como López Giraldo, quien cerraba su obra de 1936 considerando que "cuando las masas, desde el punto de vista multitudinario, se muestran inferiores a los imperativos de su época”, ellas deberán "apelar a un diferente recurso, cual sería, por ejemplo, acrecentar en un pequeño grupo el afán redentor, a fin de que tal grupo, CON UNA FINALIDAD SOCIAL, considere la conveniencia de la perpetración delatentado personal, por razones político-sociales". ${ }^{109}$ Estas consideraciones, efectivamente, constituyen un camino político que exacerba a todo nivel algunos de los postulados más importantes del unirismo: la concreción de una minoría vanguardista que transformara al pueblo a pesar de sí mismo y a través de la violencia.

Sin embargo, desde 1933 hasta finales de 1935, la propuesta revolucionaria unirista nunca se propuso una tarea como la que sugiere López Giraldo. En cambio, la UNIR planteó la transformación del establishment sin desconocer los mecanismos electorales y reivindicando el etapismo como forma realista para hacer la revolución en el país. Así, la figura de la disolución parece ser la más acertada para caracterizar el fin de la UNIR, no porque se le entienda como sinónimo de finalización consciente y arbitraria del líder, sino justamente, como dilución -o, mejor dicho, subsunción- de sus elementos al interior de otra agrupación. Al igual que la densidad de la pintura se disuelve en el agua, la UNIR se integró al campo solidario del Partido Liberal hasta disolverse en él. Esto, no obstante, tendría consecuencias tanto para el liberalismo como para Gaitán y sus adeptos: todos ellos no serían los mismos -en términos identitarios-después de la experiencia unirista.

\footnotetext{
${ }^{109}$ López Giraldo, El apóstol desnudo, 175-176. - las mayúsculas son del original, el resaltado es nuestro.
} 


\section{Referencias bibliográficas}

\section{Fuentes primarias}

Fondo Académico Jorge Eliécer Gaitán Ayala, Archivo Central e Histórico, Universidad Nacional de Colombia, Bogotá. Sección: "Adhesiones uniristas".

\section{Impresas}

\section{Publicaciones periódicas}

Unirismo, Bogotá, mayo (1934) - junio (1935)

\section{Fuentes secundarias}

Aboy Carlés, Gerardo. Las dos fronteras de la democracia argentina. La reformulación de las identidades políticas de Alfonsín a Menem. Rosario: Homo Sapiens, 2001.

Aboy Carlés, Gerardo. "De lo popular a lo populista o el incierto devenir de la plebs". En Aboy Carlés, Gerardo, Sebastián Barros y Julián Melo, Las brechas del pueblo. Reflexiones sobre identidades populares y populismo, 17-40. Los Polvorines: UNGS-UNDAM Ediciones, 2013.

Arias Trujillo, Ricardo. Losleopardos. Una historia intelectual de los años 1920. Bogotá: Uniandes Ediciones, 2007.

Aricó, José. Mariátegui y los orígenes del marxismo latinoamericano. México DF: Siglo XXI, 1980.

Ayala Diago, César. “La UNIR: entre Gaitán y los gaitanistas”. En La división creadora: influjo de las disidencias en el Liberalismo colombiano, editado por Rodrigo Llano Isaza. Bogotá: Academia Liberal de Historia, 2005, 135-152.

Azzolini, Nicolás y Sebastián Giménez. "Introducción”, en: Identidades políticas y democracia en la Argentina del siglo XX. Buenos Aires: Teseo, 2019, 9-21.

Bergel, Martín. "Populismo y cultura impresa: la clandestinidad literaria en los años de formación del Partido Aprista Peruano". Ipotesi 17 (2013): 135-146.

Carnovale, Vera. Los combatientes. Historia del PRT-ERP. Buenos Aires: Siglo XXI, 2011.

Charry-Joya, Carlos Andrés. “Unirismo y Pluma Libre. Expresiones y transformaciones de la prensa gaitanista de los años 30". Sociedad y economía 38 (2019): 64-88. https://doi.org/10.25100/sye.v0i38.7134

Gaitán, Jorge Eliécer. El Debate sobre las bananeras. Bogotá: Centro Gaitán, 1988.

Gaitán, Jorge Eliécer. Las Ideas socialistas en Colombia. Bogotá: Centro Gaitán 1988.

Gaitán, Jorge Eliécer. Los mejores discursos. Bogotá: Jorvi, 1968.

García, Antonio. Gaitán y el camino de la revolución colombiana. Bogotá: Ediciones Camilo/CEDIS, 1974.

Green, John. "Sibling Rivalry on the Left and Labor Struggles in Colombia during the 1940s". Latin American Research Review: 35: 1 (2000): 85-117. 
Green, John. Gaitanismo, liberalismo de izquierda y movilización popular. Medellín: EAFIT, 2013.

Gutiérrez Sanín, Francisco, Juan Manuel Viatela y Tatiana Acevedo, “¿Olivos y aceitunas'? Los partidos políticos colombianos y sus bases sociales en la primera mitad del siglo XX", Análisis Político 62 (2008): 3-24.

Gutiérrez Sanín, Francisco. La destrucción de una República. Bogotá: Taurus-Universidad Externado, 2017.

Jiménez Panesso, David. "Revolución: imágenes, ideas, relatos". En La República Liberal: sociedad y cultura, editado por Rubén Sierra Mejía. Bogotá: Universidad Nacional de Colombia-Facultad de Ciencias Humanas, 2009, , 391-444.

Joven Bonelo, Ana María. "El movimiento campesino en Cundinamarca. Una mirada desde la ideología y la cultura (1930-1946)". Tesis de Maestría en Sociología, Universidad Nacional de Colombia, 2016.

Koselleck, Reinhart. Futuro pasado: para una semántica de los tiempos históricos. Barcelona: Paidós, 1993.

Lenin, Vladimir Ilich. Obras completas. Tomo V. Madrid: Akal, 1976.

Mariátegui, José Carlos. "Dos concepciones de vida”. En José Carlos Mariátegui: Obras, editado por Francisco Baeza, Tomo I. La Habana: Casa de las Américas, 1982, , 407-411.

Medina, Medófilo. Historia del Partido Comunista de Colombia. Bogotá: CEIS, 1980.

Medina, Medófilo. “Los terceros partidos en Colombia. 1900-1960”. En Nueva historia de Colombia, editado por Âlvaro Tirado Mejía, Volumen II. Bogotá: Planeta, 1989, 263-294.

Meschkat, Klaus. “La herencia perdida. Movimientos sociales y organización revolucionaria en la década de 1920: el caso del Partido Socialista Revolucionario en Colombia”. En El marxismo en Colombia, editado por Orlando Fals Borda Bogotá: Universidad Nacional de Colombia-Facultad de Ciencias Humanas, 1983, 145169.

Mosquera, José Gabriel. “Unirismo: conformación de las luchas socialistas en Colombia". Tesis de licenciatura en Ciencias Sociales, Universidad Nacional de Colombia, 1982.

Núñez, Luz Ángela. "Marxistas, liberales y antifascistas. Configuración de una izquierda en Colombia (1930-1951)". Tesis doctoral en Historia, Universidad de los Andes, 2014.

Osorio Lizarazo, José Antonio. Gaitán: vida, muerte y permanente presencia. Bogotá: El Áncora, 1998.

Pécaut, Daniel. Orden yviolencia.Evolución socio-política de Colombiaentre 1930-1953. Bogotá: Norma, 2001.

Robinson, Joy Cordell. El movimiento gaitanista en Colombia: 1930-1948. Bogotá: Tercer Mundo, 1976.

Rodríguez Franco, Adriana y Gilberto Parada. “Jorge Eliécer Gaitán y el positivismo: una construcción ideológica y jurídica”. Revista Goliardos 11 (2006): 13-31. 
Sánchez, Gonzalo. “Los bolcheviques del Líbano”. En Gonzalo Sánchez, Ensayos de historia social y política del siglo XX. Bogotá: El Áncora Editores, 1985, 11-111.

Sánchez, Gonzalo. Las Ligas campesinas en Colombia. Auge y reflujo. Bogotá: Tiempo Presente, 1977.

Sharpless, Richard. Gaitán of Colombia. A Political Biography. Pittsburgh: University of Pittsburgh Press, 1978.

Tirado Mejía, Álvaro. “López Pumarejo: La Revolución en Marcha”. En Nueva Historia de Colombia, editado por Álvaro Tirado Mejía, Volumen II. Bogotá: Planeta, 1989, 305-348.

Trotsky, León. Historia de la Revolución Rusa. Buenos Aires: RyR, 2007.

Vanegas Useche, Isidro. "Apóstoles del pueblo. El carácter de los liderazgos revolucionarios en Colombia, 1924-1930”. Historia y sociedad 25 (2013): 45-77. 